\title{
Barbara Schmitz Aspects of Worship in the Letter of Aristeas
}

\begin{abstract}
Although the Letter of Aristeas mentions the translation of the Jewish nomos into Greek, it is striking that worship is not a fundamental theme of this writing. Nevertheless, six passages present acts of worship, which recount worship from different perspectives: Aristeas prays to God and explains his "Greek" idea of worship (Let. Aris. 17), whereas in Let. Aris. 132-140 the high priest explains the Jewish concept of worship. Sacrifices and prayers at the temple in Jerusalem for the Ptolemaic royal house are told in Let. Aris. 45, while at the Ptolemaic court in Alexandria one of the Jewish scholars prays at the beginning of the symposium (Let. Aris. 184-186). Then the daily prayer of the Jewish scholars are recounted in Let. Aris. 305-306 and finally the Ptolemaic king performs a proskynesis before the law at the end of the letter and thereby accepts the translation (Let. Aris. 317).
\end{abstract}

Keywords: Aristeas; Letter of Aristeas; worship; proskynesis

\section{Introduction}

For the following considerations, "worship" is to be understood as a communicative interdependence which manifests itself in certain courses of action. As a communicative interdependence, it is in most cases a repeatable communicative course of action, which comprises fixed rites and rituals. Even if worship happens spontaneously, it mostly draws on familiar forms, words and rituals, or these are put together in new combinations.

Worship as a communicative course of action manifests itself in different ways. One of them is prayer in its different forms: the prayer of the individual and community prayer, the public and the private, the spoken and the silent prayer. One of the most important forms of communication, especially in the ancient world, were the forms of cult at temples and places of worship: the different sacrifices, ritual acts, forms of worship, music and songs, as well as festivals. Moreover, prophetic communication contexts are also included, such as symbolic acts, forms of speech, ecstasy, etc., as well as blessings, maintaining text traditions or scriptures. Even thinking and speaking about God is counted here in a wider sense as worship.

All of these forms of communication create closeness to a deity. This closeness to a transcendent dimension that cannot be experienced in the same form 
as other people and objects in everyday life, but whose presence is experienced in a different way, creates at the same time a distance to one's own environment. This means that, in the context of lived worship, one's own present, issues and crises are newly and differently experienced and interpreted. Thus worship can provide security, particularly in situations of uncertainty and instability, or it can help in major crises to find a language in order to find a way out of the helplessness. Because this process is not just a process of individuals, but usually takes place in groups, belonging to the group in itself provides a feeling of security. In other words, worship also has the function of holding together a group, of emphasizing and living the affiliation of individuals to a community. Worship is thus formation of identity in practice and acts to stabilize the system and affirm it.

This formation of identity is not seen by practitioners as a one-way street, but it is supported by the idea that worship is a dialogue and not a monologue: one assumes that there is a response-no matter what form it might take-from the deity which can be experienced and decoded by the petitioner.

The writing usually designated as "Letter of Aristeas," but more appropriately

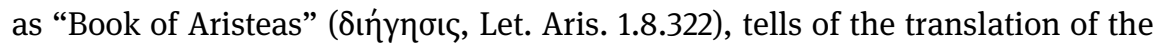
Torah into Greek-at least the contents of the Book of Aristeas are usually summarized as such-and thus portrays in legendary form how the Septuagint came about. ${ }^{1}$

The translation of Holy Scriptures-which are here, as in the case of the Torah, extremely central to the formation of the identity of Israel-is a process which needs justification: Can Holy Scriptures ever be translated? Is it permissible to translate Holy Scriptures?

The very existence of the Greek Bible, and also of the Book of Aristeas as its own scripture, themselves affirm these questions, but at the same time show that this step must be justified. Against this background, it is striking that worship is not a central theme of the Book of Aristeas. Different forms of worship are found more in passing, they are not important elements of the plot. It is all the more interesting to ask where and how worship is addressed in its various aspects. For this purpose, seven texts will be examined below. ${ }^{2}$

1 See MeISner, Aristeasbrief; Honigman, The Septuagint; CoOK and VAN DER KooIJ, Law; Matusova, The Meaning.

2 It is not only interesting where worship can be found, but also where it is not found. For example, no evidence of worship is found in the passages of the Book of Aristeas which have to do with the translation of the law (here e.g. Let. Aris. 29-31; 38; 176 etc.). Likewise, no acts of 


\section{Aristeas prays to God: the "Greek" concept of worship (Let. Aris. 17)}

The first scene in which forms of "worship" are to be found is when Aristeas took the opportunity, while the king and Demetrius wanted to have a transla-

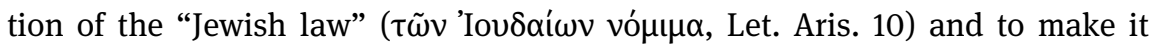
available in the Library of Alexandria, to seek audience before the king to plead for the release of Jewish prisoners of war. In a speech (Let. Aris. 15-16), he turns to the king. The reaction of the king to Aristeas' request is hesitation: "The king

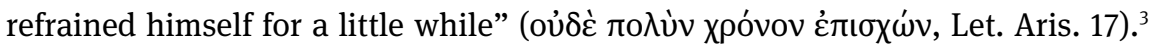
In this moment of silence and uncertainty about the imminent reaction of the

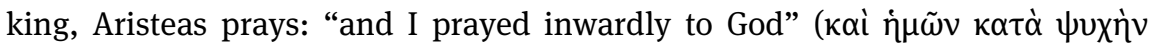

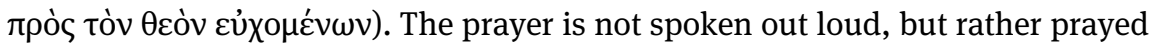

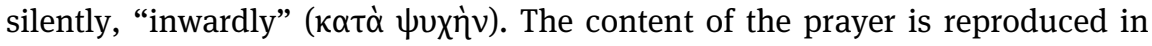
the following, in indirect speech: "to prepare his mind for a general release. Human beings, since they are creatures of God, are turned by him and swayed." It continues: "and therefore repeatedly and in various terms I called upon him who rules the heart that the king might be constrained to fulfill my petition" (Let. Aris. 17).

But who is the God to whom Aristeas prays here? There is no specification of the deity using a divine name, instead the deity is simply called "God.” To get a more precise idea about this first prayer scene described in the Book of Aristeas, not only should the question be raised as to the deity to whom Aristeas prays, but also about the petitioner himself, Aristeas.

Aristeas is presented as the Greek-writing text-internal author of the text in the Book of Aristeas. ${ }^{4}$ Thus Aristeas is the narrative voice, the narrator (intradiegetic). At the same time Aristeas appears as a character in the text world (homodiegetic). The narrative voice and figure of Aristeas introduces himself as a

\footnotetext{
sacrifice, cult or prayer are found in the description of the authorization of the law (Let. Aris. 308-311). It is also unclear whether or to what extent the purity regulations and other forms of everyday Jewish life which are described are to be counted in the area of worship. These are mentioned in the response of the high priest to the questions of the Egyptian delegation (Let. Aris. 142-171), which had inquired into the legislative provisions relating to food, drink and animals regarded as unclean (Let. Aris. 127). It is striking, however, that in the question as well as in the reply, the legal provisions are at no point connected to forms of worship or to formula-

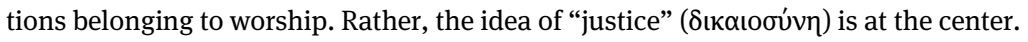

3 The translation follows HADAS, Aristeas.

4 See Genette, Figures.
} 
Greek and non-Jew (Let. Aris. 16; 121-171), who was working as a high court official at the court of King Ptolemy II (Let. Aris. 1-8). In addition, he presents himself as an active writer who had already written a text (Let. Aris. 6) and has planned other publication projects (Let. Aris. 322).

The figure of Aristeas as the intradiegetic-homodiegetic narrative voice must be clearly distinguished from the pseudonymous writer/author of the Book of Aristeas, who could possibly have been a Jew. These distinctions between narrator and writer/author are crucial to understanding the Book of Aristeas. ${ }^{5}$

If Aristeas is therefore Greek and a high court official at the king's court, he is likely to have directed his prayer to a deity corresponding to the cultural, political and theological context of the Ptolemaic court. ${ }^{6}$ The only concrete evidence of a "Greek-Ptolemaic" deity throughout the entire Book of Aristeas is found immediately before this scene. In the speech addressed to the king before the prayer, Aristeas explains that-from his "Greek" perspective-the god of Jews is to be equated with the deity who occupies the position of supreme deity in the Greek system, and that is Zeus:

God, the overseer and creator of all things, whom they worship, is he whom all men worship, and we too, Your Majesty, though we address him differently, as Zeus and Dis

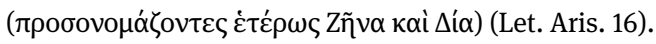

According to Aristeas, God has the same function in the Jewish and in the Greek context: he is the creator and overseer of all things. The only difference is God's name: In the Greek context, God is called “Zeus.” As Aristeas points out, this is

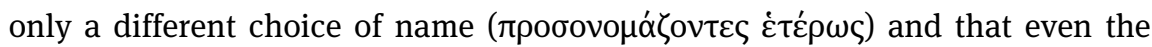

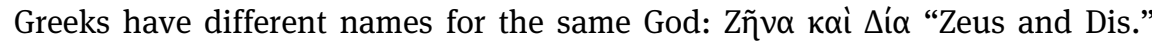
More interesting than the subtle wordplay is the fact that Aristeas identifies God, "whom all humans worship," with the God of the Jews. This idea is often

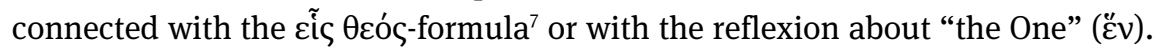
The background of the replacement of Zeus and "God," as Aristeas argues,

5 WRIGHT, The Letter of Aristeas, 16.19: “Aristeas's author cannot be identical with the narrator... By writing in the voice of a Gentile narrator, our author reassures his educated Jewish coethnics/religionists that the Gentile who occupy the upper strata of Hellenistic Alexandrian society understand and accept Jews as Jews." Therefore, Wright uses the definition: "I designate the Book as Aristeas (using italics), our author as Ps.-Aristeas, and his main character as Aristeas (without quotation marks)" (20). See also WRIGHT, Pseudonymous Authorship, 43-62.

6 Therefore, I have decided not to write the renominalization of God capitalized as "He," "Him" "His" in the translation as Hadas does. With the capitalization, a reference to the God of Israel is suggested, who in my opinion is simply not present here, cf. HADAS, Aristeas.

7 See STAUdT, Der eine und einzige Gott. 
seems to be the Greek philosophical, probably Stoic context. ${ }^{8}$ The first use of the

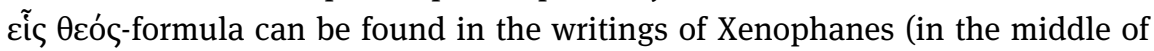
the $6^{\text {th }}$ century BCE). ${ }^{9}$ For Xenophanes, there is one God and this one God has no name. In the Stoa this discussion of the Presocratics is continued, but in a slightly different way. Zeno of Citium (335-262 BCE) says: "God is one and the same with Reason, Fate, and Zeus $(\Delta i \dot{i})$; he has also called by many other names (

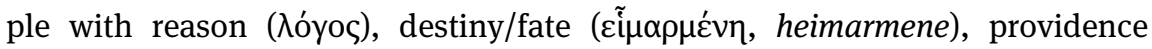
( $\pi$ póvoı $\alpha$, pronoia), but also with God ( $\theta \varepsilon$ cos), Zeus or the power of thoughts of Zeus. ${ }^{10}$ Zenon's identification is adopted by his students (Cleanthes, Chrysippos and others). One example is the well-known ${ }^{11}$ hymn to Zeus (approx. 280 BCE) written by Cleanthes of Assos (died 230/229 BCE), in which he combines traditional and mythological motifs with ideas of Greek philosophers, esp. with a Stoic interpretation of Heraclitus: "Noblest of immortals, many-named $(\pi о \lambda \nu \omega ́ v v \mu \varepsilon)$, always all-powerful Zeus, first cause and ruler of nature, governing everything worth your law, greetings!"12 Chrysipp of Soloi (281/277-208/204 BCE) also describes the deity as without a human form or gender, but as eternal and everlasting logos, which can be called "Zeus." 13 This philosophical, especially Stoic context seems to be the background for the statement from Let. Aris. 15-16, namely the idea that there is one Deity with the name "Zeus." Therefore, Aristeas is presented as a philosophically, maybe Stoic educated character. Therefore, Let. Aris. 15-16 is not, as widely acknowledged, a Jewish tradition, but rather a philosophical-stoical position which seems to be well-known in JewishHellenistic contexts.

For the understanding of the first prayer scene in the Book of Aristeas, this means that the first prayer from the "Greek" Aristeas could be directed to his (highest) deity, Zeus. This deity is designated by Aristeas as "overseer"

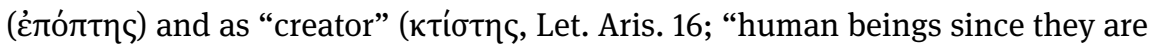

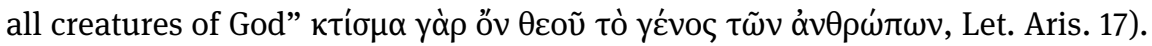
"Overseer and creator" are rarely used Jewish descriptions for the God of Is-

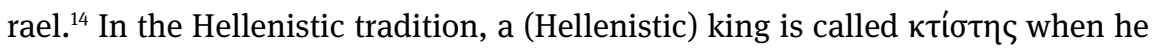

8 Schmitz, Using Different Names (forthcoming).

9 See FreEMAn, The Pre-Socratic Philosophers, 95.

10 Cf. Steinmetz, Die Stoa, 535.537.539.606.

11 See e.g. Acts 17:28.

12 The translation follows THом, Cleanthes' Hymn to Zeus, 40.

13 Cf. SteInmetz, Die Stoa, 609.

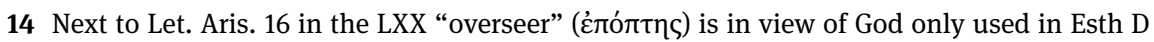

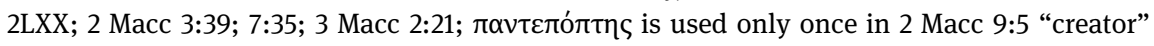




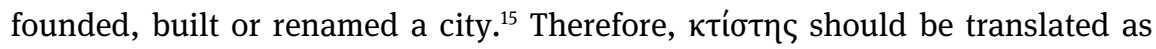

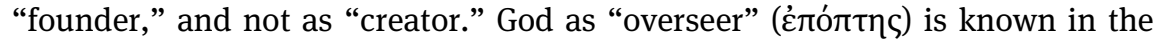
Greek tradition (i.e. Epicharmos: "he himself is our overseer and nothing is impossible to him, God," frag. 23). Neither of these are genuine areas of traditional expertise of Zeus, which shows that it has nothing to do with the Olympic divinity, but rather that "Zeus" here, in the Stoic tradition, serves the purpose of a cipher that indicates the divine, and therefore comprehensively stands for a deity who is behind everything else. In this sense, Aristeas describes the deity to whom he turns: "God, who is the Lord of all, guides their [= human beings]

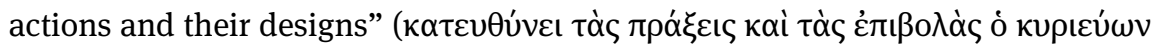

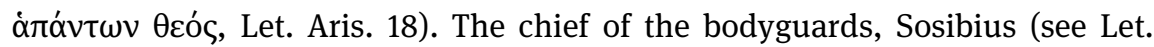
Aris. 12), present at the scene, expresses himself in a similar manner; he speaks not only of a "supreme deity," but even refers to the release of Jewish prisoners

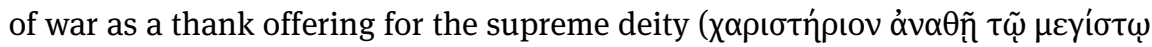

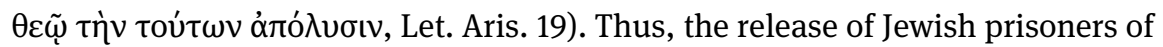
war is not only a fact with which the king can show himself as a philanthropic, good king (see $\varphi \iota \lambda \alpha ́ v \theta \rho \omega \pi$, Let. Aris. 36) and prove his generosity ( $\mu \varepsilon \gamma \alpha \lambda$ оноьрí $\alpha$, Let. Aris. 21), it is rather at the same time an act of worship, as the king himself emphasizes in his letter to the high priest:

we, then have given liberty to above a hundred thousand captives, paying their owners proper market prices and making good whatever injury may have been inflicted through

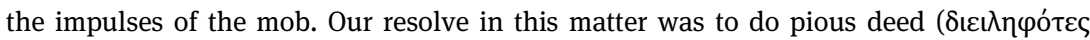

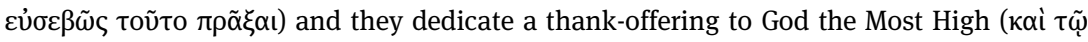

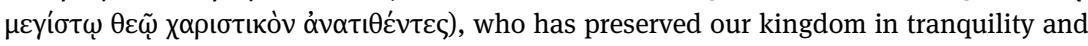
in the mightiest esteem throughout the inhabited world (Let. Aris. 37).

With the fulfillment of Aristeas' request, the deity he calls upon thus proves to be reliable: God has completely fulfilled the request of Aristeas (Let. Aris. 18 and 20).

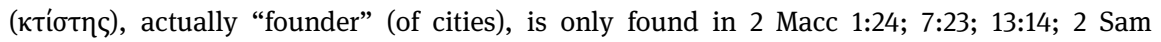

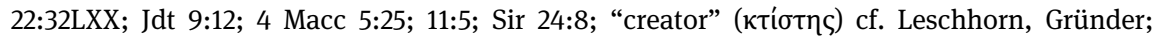
Casevitz, Le vocabulaire, 13-72; Bons and PASSONi Dell'AcQuA, A Sample Article, 173-187. The impact of the Hellenistic concept of kingship on the concept of the God of Israel cf. ScHмiтz, Tradition und (Er)Neuerung (forthcoming).

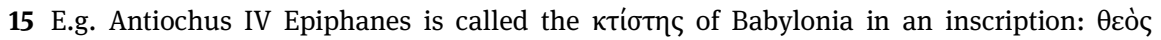

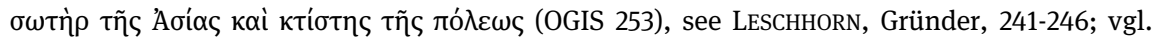

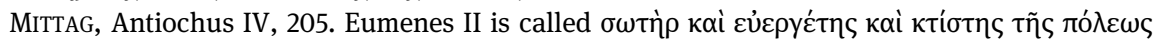
(OGIS 301). 


\section{The high priest explains the Jewish concept of worship (Let. Aris. 132-140)}

The Jewish concept of worship is different from the position represented by the Greek Aristeas, the Ptolemaic king and his court. This Jewish concept is explained by the high priest Eleazar who gives a detailed answer (ó $\mu \mathrm{\lambda} \hat{\alpha} \alpha)$ to the questions of the Egyptian delegation about the legislation regarding the dishes, beverages, and impure animals. The high priest opens his answer with an explanation about the theological fundament (Let. Aris. 131; 132-141):

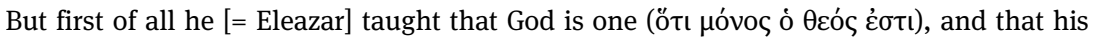

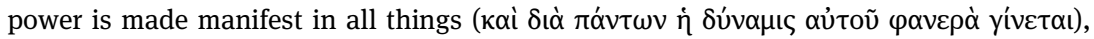
and that every place is filled with his sovereignty, and that nothing done by men on earth secretly escapes his notice, but that all that anyone does and all that is to be is manifest to Him (Let. Aris. 132).

The high priest repeats his explicit monotheistic credo in Let. Aris. 139 to the

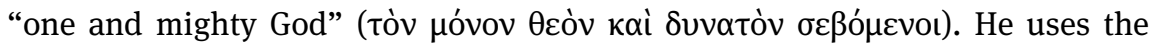
$\mu$ óvos-formula, as it is known from Isaiah II (Isa 43:11; 44:6; 45:1-6.21-22; 46:9 etc.), but also from the translated books of the LXX (Deut 32:12; 1 Sam 7:3.4; 2 Kings 19:15.19 // Isa 37:16.20; Ps 50:6 $6^{\mathrm{Lxx}}$; Isa 44:24 etc.) and the Greek books (3 Esdr 8:25; Esth C 14 [= Esth 4:171 ${ }^{\mathrm{Lxx}}$ ]; 2 Macc 7:37 etc.). In contrast to the position of Aristeas and the Ptolemaic King, the high priest represents the "traditional" Jewish position: there is one God, and there is no other, besides him, there is no God (see Isa 45:5). The high priest illustrates this in his criticism of polytheism and his criticism of the worship of images and idols (Let. Aris. 134138):

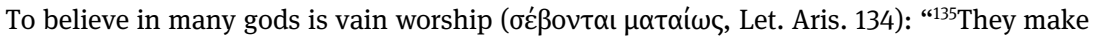
idols of stone and wood and declare that these are images of persons who made discoveries useful in life, and these they worship ( vious. ${ }^{136}$ That anyone should be made a god because of some invention he has contrived is altogether foolish; for such persons only took things already created and put them together and showed that they possessed further usefulness, but they did not themselves create the objects. Hence to deify men like themselves is idle and foolish. ${ }^{137}$ Even at this day there are many who are more inventive and more learned than the men of old, and yet they

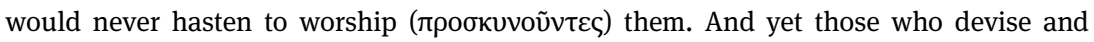
fashion such fables consider that they are the wisest of the Greeks. ${ }^{138}$ What need even to speak of other infatuated people, Egyptians and their like, who have put their reliance in

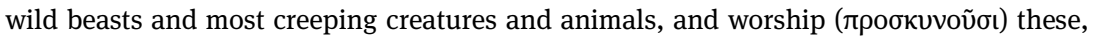
and to these offer sacrifice, whether alive or dead?" (Let. Aris. 134-138). 
In order to outline the position of the pagan polytheism and image worship, the high priest uses in particular the verb "prostrate oneself, honor, worship" ( $\pi \rho \circ \sigma \kappa u v \varepsilon ́ \omega)$. In the Book of Aristeas the verb is used throughout only for nonJews; besides Let. Aris. 135; 137; and 138 it is only used as a gesture of the Ptolemaic king (Let. Aris. 177; 317, see below).

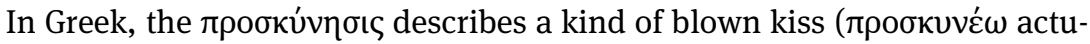
ally: "kissing toward") often associated with a certain body movement as an homage. In Greco-Roman antiquity, the proskynesis was performed strictly before deities; in the Ancient Near East, particularly in Persia under the Achaemenids, this gesture was also customary for the (not divinely worshiped) rulers (Herodotus, Hist. 3.86; 7.13; 8.118; Xenophon, Cyr. 8.3.12-14 etc.). It served the social classification of subjects: lower Persians, as well as (Greek) petitioners and subjugated persona had to connect the proskynesis with a prostration (

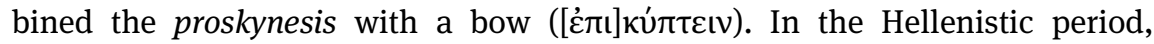
proskynesis had become a matter of course as a reverence gesture in front of the now divinely revered rulers and Roman emperors. At the time of Alexander, the question of whom the proskynesis was for was controversial. Alexander the Great had in fact tried to introduce the Persian proskynesis in his court ceremonial, namely due to his claim to the royal dignity of a king of kings. This was natural for the Persians; for the Greeks, however, the right to proskynesis was regarded as barbaric self-aggrandizement and self-deification and therefore rejected.

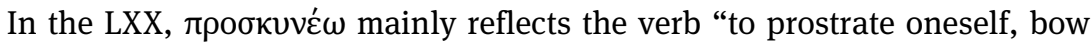
deeply" (השתחוה), used in much of the Hebrew Bible as a terminus technicus for worship, and describes the falling down on the earth, which can take place before people as well as deities. The refusal of proskynesis towards a person in the book of Esther is the motive that triggers Haman's anger towards Mordecai, and the consequence of which is the creation of the plan for the extermination of the Jews (Est 3:2,5; C 5-7; E $11^{\mathrm{Lxx}}$ ).

In contrast to the non-Jewish position outlined by the high priest, and certainly caricatured, he again profiles the Jewish concept of worship: through Moses, the lawgiver, the Jews are surrounded by the laws of "impregnable pali-

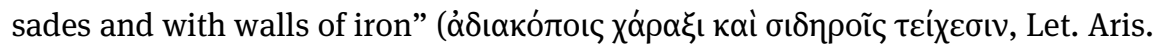
139). They are

pure in body and in spirit, emancipated from vain opinions, revering the one and mighty

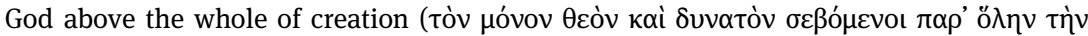

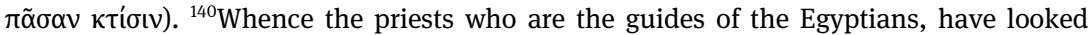
closely into many things and are conversant with affairs, have named us "men of God," a 


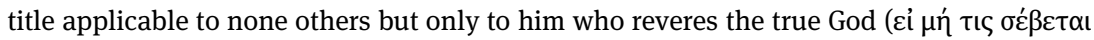

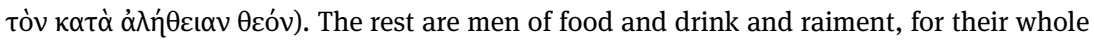
disposition has recourse to these things. ${ }^{141}$ With our countrymen, however, these things are reckoned as of worth nothing, but throughout the whole of life their contemplation is

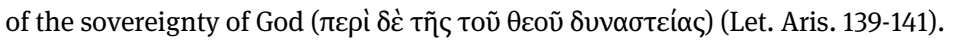

\section{Sacrifice and prayer at the Temple in Jerusalem for the Ptolemaic royal house}

Another act of worship, which is described in the Book of Aristeas, is a primarily cultic act. In the response letter from the high priest to the Ptolemaic king, Eleazar writes that he offered a sacrifice for the Ptolemaic royal house at the temple in Jerusalem and prayed publicly for it.

We have therefore straightway offered sacrifices ( $\theta v \sigma i ́ \alpha \varsigma)$ on your behalf and on the behalf of your sister and children and friends, and the entire multitude prayed ( $\eta$ $\xi \alpha \tau o$ ) that your

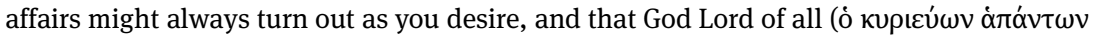
Өcós) might preserve your kingdom in peace and with honor (Let. Aris. 45).

That the high priest offers sacrifices for the Ptolemaic royal house is repeated in Let. Aris. 172.

This is the only place where a sacrificial act is described. Otherwise, the cultic context in the Book of Aristeas is in this respect very present, because among the gifts sent by the king to Jerusalem, cultic objects can be found which are described in detail (see Let. Aris. 33; 40). Here it is a detailed description of the table (Let. Aris. 51-72), the bowls (Let. Aris. 73-78) and the golden flagons (Let. Aris. 79-82). In response, Eleazar emphasizes that the gifts were understood by

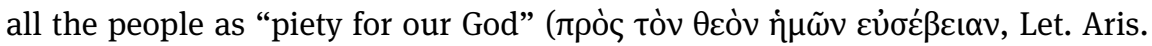
42). The description of the temple of Jerusalem (Let. Aris. 84-91) and of the altar (Let. Aris. 87-88), each of which is described in detail, are also part of the ritual dimension. In this context, the tasks of the priest (Let. Aris. 92-95) and of the high priest (Let. Aris. 96-99) are also described in detail. 


\title{
5 Prayer at the beginning of the symposium (Let. Aris. 184-186)
}

Another prayer can be found at the beginning of the symposium. As usual in an ancient symposium, it is opened by sacrificial offerings. But other than usual, the king prohibits-as told in Let. Aris. 184-his sacred heralds and sacrificial ministers from beginning the symposium with the prayers which are usually offered. Instead the king calls on Elissaios, the eldest of the priests who traveled

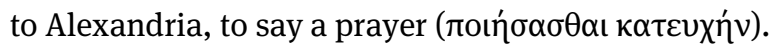

He prays:

\begin{abstract}
May Almighty God fill Your majesty full of the good things which he has created, and grant uninterrupted and lifelong possession of them to you and your wife and children

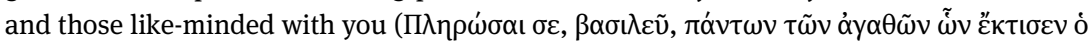

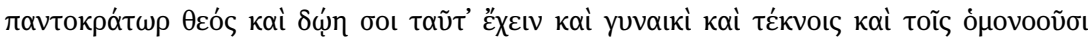

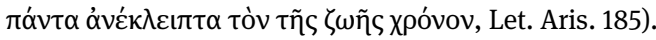

The prayer in honor of the king and his family is clever diplomatically and theologically. It is so openly formulated that it can be understood by both the Jewish participants and the participants of the Ptolemaic court, even if the respective understanding varies according to their own theological tradition. The Jewish symposium participants will think of their God, the one and only God of Israel,

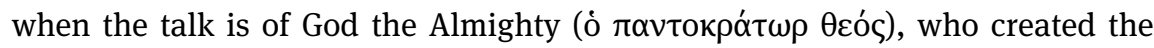
good things; the non-Jewish participants are likely to connect the prayer with the philosophical, perhaps Stoic concept of God as it is likely to be known and represented at the Ptolemaic court (cf. Let. Aris. 15-16). The fact that this theological balancing act succeeded is shown by the reaction of the audience: "At these words there was a burst of applause, and shouts and joyful jubilation continued for a considerable time" (Let. Aris. 186).

Thus, the seven-day symposium is opened, in the course of which the king asks every Jewish scholar a question which they then answer. It does not have

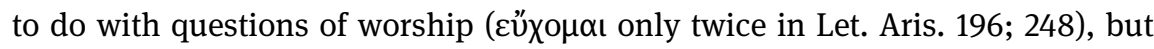
rather with good governance and responsible use of power. These are central topoi of the peri basileias-literature, which emphazise the king's righteousness /

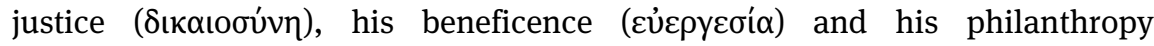

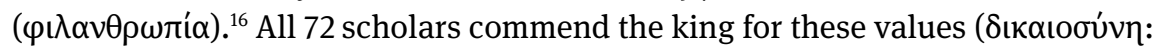

16 MURRAY, Aristeas, 337-371; MENDELs, On Kingship, 245-252; MORE, Kingship, 299-319; cf. HAAKE, Warum, 83-138, 90. 


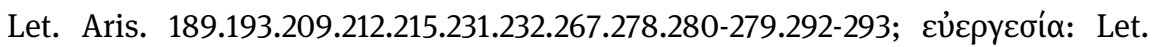
Aris. 190.205. 210.249.273-274.281.290; $\varphi \iota \lambda \alpha \nu \theta \rho \omega \pi i ́ \alpha$ : Let. Aris. 208.265.290), but more important is that, in all 72 answers, "God" is the central aspect. The Jewish scholars recommend the king as an imitatio dei, an imitatio dei of the God of Israel (explicitly in Let. Aris. 281).

\section{The daily prayer of the Jewish scholars}

Another time, the reference to forms of worship is found in Let. Aris. 305 and 306 , in a description of what the daily life of the translators is like:

Every day they would come to the court early in the morning, and when they had made their salutations to the king they departed to their own place. ${ }^{305}$ When they had washed their hands in the sea, as is the custom of all Jews, and had offered their prayers to God

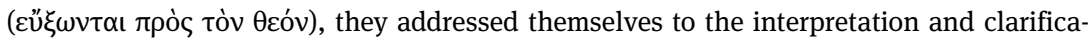
tion of each passage (Let. Aris. 304-305).

The fact that the Jewish scholars wash their hands before praying amazed Aristeas: "I questioned them on this point too, why it was that they washed their

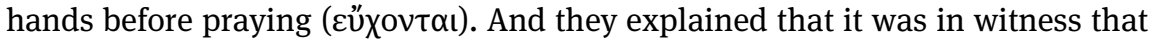
they had done no wrong, since the hands are the organs of all activity" (Let. Aris. 306).

\section{The king performs a proskynesis before the Law}

A final aspect which falls within the area of worship could be the scene in which the king performs a proskynesis ( translation, and orders that great care be taken of the books and that they be watched over reverently:

And after the king, as I have already said, had received the explanation from Demetrius on

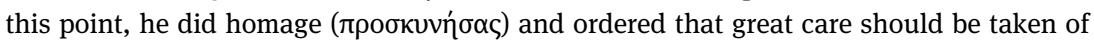
the books, and that they should be sacredly guarded (Let. Aris. 317).

It is not the first, but the second time that the king performs a proskynesis before the Jewish law. The first time this took place was as the rolls arrived in Alexandria: 
When they had uncovered the rolls and had unrolled the parchments the king paused for

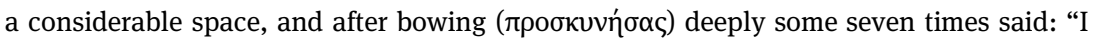
thank you, good sirs, and him that sent you even more, but most of all I thank God whose holy words these are” (Let. Aris. 177).

Taking both scenes together, both of which are connected by the word $\pi \rho \circ \sigma \kappa v v \varepsilon \dot{\varepsilon} \omega$, the context of worship is clear: The Ptolemaic king makes a proskynesis before the Jewish law! This provides a reversal of roles: instead of the scholars honoring him with a proskynesis, he honors the scroll and the translation. In this scene, the two lines of worship in the Book of Aristeas, the Ptolemaic and the Jewish, come together. Here they are not only merged, but rather it is told how the Ptolemaic king honors the Jewish Torah scrolls and their translation by a proskynesis. Thus the Book of Aristeas not only gives the Jewish way of worship, but also the translation of the Greek Bible a dignity which acts to stabilize the system and affirm identity.

\section{Conclusion}

The survey shows that there are divers and varied aspects of worship in the Book of Aristeas. The different aspects of worship are shown first of all by the

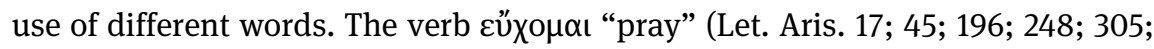
306) as a general term for the invocation of a deity can be found for prayer by Jewish figures in the narrative as well as for those of the Ptolemaic court. The

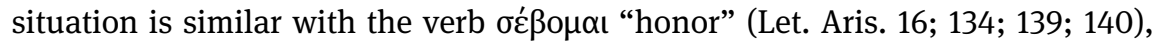
which can be used for the Greek side (Let. Aris. 16) as well as for the Jewish polemic against polytheism and image worship (Let. Aris. 134), but also for the

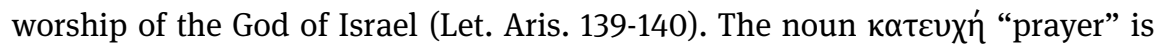
used once for the usual prayer before an ordinary symposium in the context of the customary cultic rites, but it is also used for the Jewish prayer (Let. Aris.

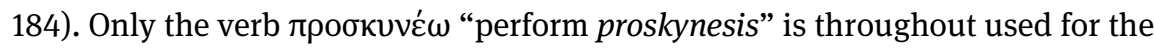
Greek side (Let. Aris. 135; 137; 138; 177; 317).

Only once is there a directly cited and loudly spoken prayer (Let. Aris. 184); once a prayer that is silent or spoken internally is cited in indirect speech (Let. Aris. 17); then only once it is mentioned that, and especially how, one is to pray (Let. Aris. 305; 306; other forms of worship, sacrifice and prayers in Let. Aris. 45; 132-140).

Within the seven passages explained here, very different constellations of worship can be found: forms of worship on the Jewish side are described and forms of worship are outlined which take place at the Ptolemaic court and rep- 
resent "pagan” ideas (Let. Aris. 17). Aristeas represents a philosophical concept of God, probably inspired by Stoic thoughts, in which the one, greatest God, who can be referred to as "Zeus," is presumed behind all other outward forms.

The Jewish concept of God and worship, which is an exclusive-monotheistic concept, is explained by high priest Eleazar. In addition, sacrifices at the temple of Jerusalem can be taken for granted and have a strong presence through the detailed descriptions of sacrifice, sacrificial implements and the temple itself. As the sole sacrificial act itself, a sacrifice and prayer for the Ptolemaic royal house is mentioned (Let. Aris. 45).

The "normal" way of Jewish prayer is experienced by the readers in the description of the daily prayer rite of the Jewish scholars, which is connected to a washing (Let. Aris. 305; 306). This is described through the eyes of Aristeas, that is, described from an external perspective and opened up in their interest.

As a last and final worship scene, the Ptolemaic king makes a proskynesis before the translation of the Jewish law (Let. Aris. 317). It is probably no coincidence that this last worship scene is at the end of the Book of Aristeas. In the final scene the two strands of worship, the Ptolemaic and the Jewish side, come together. While in the narrative the various constellations of worship have been run through, the book ends with the fact that even the Ptolemaic king honors Jewish law with his proskynesis. Thus the arrival of the scrolls in Alexandria stands at the end of the story. The newly translated work is thus proclaimed as what the Ptolemaic king already formulated in Let. Aris. 177: “...most of all I thank God whose holy words these are”.

\section{Bibliography}

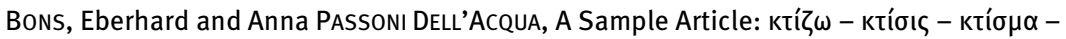
Ktíotns, in: idem and J. Joosten (eds.), Septuagint Vocabulary. Pre-History, Usage, Reception (SBLSCS 58), Atlanta: SBL 2011, 173-187.

CASEVITZ, Michel, Le vocabulaire de la colonisation en grec ancien, Paris: Klincksieck 1985. COOK, Johann and Arie VAN DER KOOIJ, Law, Prophets, and Wisdom. On the Provenance of Translators and their Boks in the Septuagint Version (CBET 68), Leuven: Peeters 2012.

Diogenes Laertius, Lives of Eminent Philosophers (transl. R.D. Hicks), Cambridge: Harvard University Press 1979.

Freeman, Kathleen, The Pre-Socratic Philosophers. A companion to Diels, Fragmente der Vorsokratiker ( $2^{\text {nd }}$ ed.), Oxford: Blackwell 1966.

GENETTE, Gérard, Figures of Literary Discourse, New York: Columbia University Press 1998.

HAAKE, Matthias, Warum und zu welchem Ende schreibt man peri basileias? Überlegungen zu einem Kontext einer literarischen Gattung im Hellenismus, in: K. Piepenbrink (ed.), Philosophie und Lebenswelt in der Antike, Darmstadt: WBG 2003, 83-138. 
HAdAS, Moses, Aristeas to Philocrates (Letter of Aristeas), New York: Harper 1951.

Honigman, Sylvie, The Septuagint and Homeric Scholarship in Alexandria. A Study in the Narrative of the Letter of Aristeas, London: Routledge 2003.

LESCHHORN, Wolfgang, Gründer der Stadt. Studien zu einem politisch-religiösen Phänomen der griechischen Geschichte (Palingenesia 20), Wiesbaden: Steiner 1984.

MATUSOVA, Ekaterina, The Meaning of the Letter of Aristeas. In the Light of Biblical Interpretation and Grammatical Tradition, and with Reference to its Historical Context (FRLANT 260), Göttingen: Vandenhoeck \& Ruprecht 2015.

MEISNER, Norbert, Aristeasbrief (JSHRZ II.1), Gütersloh: Gütersloher 1973.

MENDELS, Doron, “On Kingship” in the Temple Scroll and the Vorlage of the Symposia in the Letter of Aristeas to Philocrates: Shnaton 3 (1979) 245-252.

MItTAG, Peter F., Antiochus IV. Epiphanes. Eine politische Biographie (Klio. Beihefte Neue Folge 11), Berlin: Akademie Verlag 2006.

MORE, Jonathan, Kingship ideology: A neglected element in Aristeas' charter myth for Alexandrian Judaism, in: J. Cook (ed.), Septuagint and Reception. Essays prepared for the Association for the Study of the Septuagint in South Africa, Leiden: Brill 2009, 299-319.

MURRAY, Oswyn, Aristeas and Ptolemaic Kingship: JTS 18 (1967) 337-371.

SCHMITZ, Barbara, “...Using Different Names, as Zeus and Dis" (Arist 16). Concepts of "God" in the Letter of Aristeas, in: S. Kreuzer, M. Meiser and M. Sigismund (eds.), Die Septuaginta - Orte und Intentionen (WUNT), Tübingen: Mohr Siebeck (forthcoming).

SCHMITZ, Barbara, Tradition und (Er)Neuerung. Die Rede von Gott in jüdisch-hellenistischer Literatur: TLZ (2016) (forthcoming).

STAUDT, Darina, Der eine und einzige Gott. Monotheistische Formeln im Urchristentum und ihre Vorgeschichte bei Griechen und Juden (NTOA 80), Göttingen: Vandenhoeck \& Ruprecht 2012.

Steinmetz, Peter, Die Stoa, in: H. Flashar (ed.), Die Philosophie der Antike. Band 4: Die hellenistische Philosophie, Basel: Schwabe 1994.

THOM, Johan C., Cleanthes' Hymn to Zeus. Text, Translation, and Commentary (STAC 33), Tübingen: Mohr Siebeck 2005.

WRIGHT, Benjamin G., Pseudonymous Authorship and Structures of Authority in the Letter of Aristeas, in: G.G Xeravits et al. (eds.), Scriptural Authority in Early Judaism and Ancient Christianity (DCLS 16), Berlin: de Gruyter 2013, 43-62.

WRIGHT, Benjamin G., The Letter of Aristeas. "Aristeas to Philocrates" or "On the Translation of the Law of the Jews" (CEJL), Berlin: de Gruyter 2015. 